\title{
EFFECT OF NITROGEN DEFICIENCY AND FUSARIUM GRAMINEARUM INFECTION ON RELATIVE CHLOROPHYLL CONTENT OF MAIZE SEEDLINGS
}

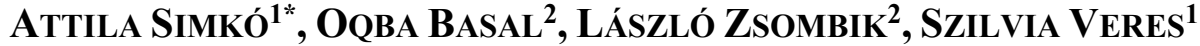 \\ ${ }^{1}$ University of Debrecen, Faculty of Agriculture, Food Science and Environmental \\ Management, Institute of Crop Sciences, Department of Agricultural Botany, Crop \\ Physiology and Biotechnology, Debrecen, Hungary \\ ${ }^{2}$ University of Debrecen, Institutes for Agricultural Research and Educational Farm, \\ Research Institute of Nyíregyháza, Nyíregyháza, Hungary \\ *Corresponding author: simko.attila@agr.unideb.hu
}

\begin{abstract}
Nowadays the global climate change significantly affects the agricultural production due to different biotic and abiotic stresses. Phythopathogens, like fusarium, can cause serious injury which could be worsened by climatic conditions. The goal of our experiment was to examine the single and the combined effect of nitrogen $(\mathrm{N})$ deprivation and Fusarium graminearum infection on the physiology of some maize genotypes. Furthermore, we would like to know the impact of the mentioned factors on the rate of nitrogen remobilization and relative chlorophyll content (SPAD value) of leaves with different ages. Controlled pot experiment was set up in a climate room, maize (Zea mays L.) genotypes were grown using hydroponic conditions. Inoculation of Fusarium graminearum conidia was performed as a biotic stress at 5-leaf (V5) stage of the seedlings and two $\mathrm{N}$ level were used during the experiment: optimal $\mathrm{N}$ and a quarter of it from the beginning. Our results suggest that $\mathrm{N}$ deprivation influenced the SPAD values regardless of the age of leaves and genotype. Strong interaction was found between infection and $\mathrm{N}$ level in case of the younger leaves. In these leaves the relative chlorophyll content was significantly decreased due to inoculation, but just at optimal $\mathrm{N}$ level.
\end{abstract}

Keywords: SPAD, Maize, Fusarium graminearum, Nitrogen

\section{INTRODUCTION}

The condition of stalk plays a really important role in the development of maize plants. The damage of stalk tissues ultimately led to decay or at least yield loss. The disease called 'maize stalk rot' is caused by several group of pathogens, but the most important species are Fusarium graminearum, Fusarium culmorum and Fusarium verticillioides in Europe (SCAUflaire ET AL., 2011). According to SingH ET AL. (2012) the symptoms of fusarium stalk rot appears after anthesis in maize, but Fusarium species are able to infect any part of the maize plant at any stage of development from germination to maturity (SzÖKE ET AL., 2013). BORDERS ET AL. (2007) emphasized in their study that $F$. graminearum is the most prevalent pathogen of corn seeds and seedlings. Huge differences exist among resistance levels of genotypes to fusarium stalk rot (SzÖKE ET AL., 2009; SzÖKE ET AL., 2007). BATA ET AL. (2001) found a correlation between vegetation period of maize hybrids and the level of resistance. Based on his results hybrids with longer vegetation period had lower resistance level. The interaction between plants and pathogens is complex; moreover, it can be influenced by multiple environmental factors such as temperature, humidity, light and nutrients. Among nutrients, nitrogen assimilation is related to several crucial physiological processes, so it is unsurprising that $\mathrm{N}$ supply of plants can influence plant resistance to several stresses, including biotic factors as well. HOFER ET AL. (2016) highlighted that fusarium infection in spring barley is influenced by nitrogen fertilization. MUHAMMED ET 
AL. (2010) found positive correlation between increasing the level of nitrogen and the injury level by fusarium in barley. In contrast, WHITE ET AL. (1978) claimed that the increased level of nitrogen resulted in a decrease in the harmful effects of fusarium stalk rot in maize. BAURIEGEL ET AL. (2011) claimed Fusarium infestation cannot be detected by spectral analysis immediately after infection in wheat plants. The goal of our experiment was to examine the single and combined effects of nitrogen deprivation and Fusarium graminearum infection in maize genotypes. Furthermore, we would like to know the impact of the mentioned factors on nitrogen remobilization and relative chlorophyll content (SPAD value).

\section{MATERIALS AND METHODS}

Our experimental plant was maize (Zea mays L.), two genotypes with different maturity were used (Armagnac FAO 490, P9903 FAO 390). Our experiment was controlled, plants were grown under hydroponic conditions, using the following nutrient solution: $2.0 \mathrm{mM}$ $\mathrm{Ca}\left(\mathrm{NO}_{3}\right)_{2} \cdot 4 \mathrm{H}_{2} \mathrm{O} ; 0.7 \mathrm{mM} \mathrm{K}_{2} \mathrm{SO}_{4} ; 0.5 \mathrm{mM} \mathrm{MgSO} 4 \cdot 7 \mathrm{H}_{2} \mathrm{O} ; 0.1 \mathrm{mM} \mathrm{KH}_{2} \mathrm{PO}_{4} ; 0.1 \mathrm{mM} \mathrm{KCl}$; $0.5 \mu \mathrm{M} \mathrm{MnSO}_{4} \cdot 4 \mathrm{H}_{2} \mathrm{O} ; 0.5 \mu \mathrm{M} \mathrm{ZnSO}_{4} \cdot 7 \mathrm{H}_{2} \mathrm{O} ; 0.2 \mu \mathrm{M} \mathrm{CuSO}_{4} .5 \mathrm{H}_{2} \mathrm{O}$; and $0.1 \mu \mathrm{M} \mathrm{H}_{3} \mathrm{BO}_{3}$. Iron was added in as $10^{-4} \mathrm{M}$ Fe-EDTA. For the nitrogen $(\mathrm{N})$ treatment, $\mathrm{N}$ content of the original solution was reduced to quarter $(1 / 4 \mathrm{~N})$. Plants were inoculated with $30 \mu \mathrm{l}$ Fusarium graminearum conidia suspension at the junction of the shoot and the root with injection (infected). To avoid misleading results, damage treatment was also used as a control as well (wounded). In these pots plants were wounded by a different needle which has same diameter as the needle used during infection. In addition to infected and wounded treatments, absolute control treatment was also used (control). Injection of conidia suspension was performed in the $17^{\text {th }}$ day of experiment. The relative chlorophyll contents (SPAD values) were recorded on the older $\left(3^{\text {rd }}\right)$ and the younger $\left(5^{\text {th }}\right)$ fully developed leaves with SPAD-502 (Minolta, Japan). Five measurements were performed on the middle region of each leaf, the average of these values was considered as one repetition. For characterising nitrogen remobilization ability of genotypes the nitrogen remobilization rate (NRR) was used (Nagy, 2017). For the calculation of difference between the SPAD values of oldest and youngest leaf (DSI) and normalized difference SPAD index (NDSI) the equations of Lin et al. (2010) were used. The SPAD ratio of the oldest and the youngest leaf (RSI) was calculated by the equation of Shen et al. (2002), while for the calculation of SPAD relative positional difference index between the oldest and the youngest leaf (RDSI) the equation of Wang et al. (2002) was used. We made modifications on the equations of the mentioned authors. In the original indices, $1^{\text {st }}$ leaf was considered as oldest leaf and the $3^{\text {rd }}$ leaf was the youngest. In our calculation the following equations were used:

$$
\begin{aligned}
& \text { NRR }=1-\left(\mathrm{SPAD}_{\mathrm{i}}-\mathrm{SPAD}_{\mathrm{f}}\right) \mathrm{SPAD}_{\mathrm{i}} \\
& \mathrm{DSI}=\mathrm{SPAD} \mathrm{D}_{\mathrm{i}}-\mathrm{SPAD}_{\mathrm{f}} \\
& \mathrm{RSI}=\mathrm{SPAD} \mathrm{D}_{\mathrm{i}} / \mathrm{SPAD}_{\mathrm{f}} \\
& \mathrm{RDSI}=\left(\mathrm{SPAD}_{\mathrm{i}}-\mathrm{SPAD}_{\mathrm{f}}\right) / \mathrm{SPAD}_{\mathrm{f}} \\
& \mathrm{NDSI}=\left(\mathrm{SPAD}_{\mathrm{i}}-\mathrm{SPAD}_{\mathrm{f}}\right) /\left(\mathrm{SPAD}_{\mathrm{i}}+\mathrm{SPAD}_{\mathrm{f}}\right)
\end{aligned}
$$

Where $\mathrm{SPAD}_{\mathrm{i}}$ is the relative chlorophyll content of the $3^{\text {rd }}$ leaf and $\mathrm{SPAD}_{\mathrm{f}}$ is the relative chlorophyll content of the $5^{\text {th }}$ leaf.

For statistical analysis SigmaPlot 12 for Windows (Systat Software) was used. During the data analysis, three-way ANOVA method was used with Duncan's post hoc test. 


\section{RESULTS}

Based on the results of the SPAD, data obtained from the older leaves are presented in Figure 1. In this case we did not find significant difference between genotypes. Furthermore, infection had no effect on this parameter. In contrast, $\mathrm{N}$ supply significantly affected this parameter $(\mathrm{P} \leq 0.001)$. At optimal $\mathrm{N}$ level, remarkable higher $(47.86 \%)$ SPAD values $(41.87 \pm 1.07)$ were found compared to reduced level of $\mathrm{N}(21.83 \pm 0.87)$. We did not find any interaction between the effects of treatments.

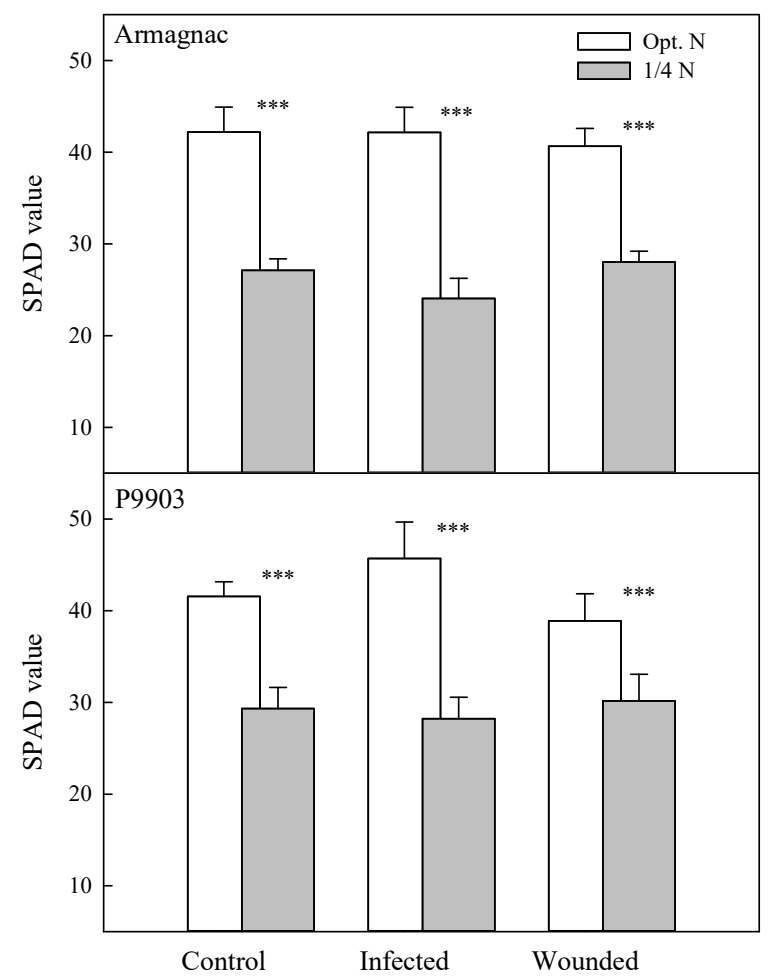

Figure 1. Changes of relative chlorophyll content (SPAD value) in the older leaves of maize hybrids (Armagnac, P9903) under different $\mathrm{N}$ supply (Opt. N, 1/4 N) and due to infection with Fusarium graminearum (Control, Infected, Wounded) $n=3$, \pm s.e. Significant differences were signed $* * *(\mathrm{p} \leq 0.001)$

In case of younger leaves significant differences were found (Figure 2) between the mean values of $\mathrm{N}$ levels regardless of other factors. In optimal level of $\mathrm{N}(39.14 \pm 1.25)$ significantly higher values were observed than in $1 / 4 \mathrm{~N}(27.07 \pm 0.88)$. Comparison of genotypes showed significant difference. In P9903 genotype, higher (10.23\%) SPAD values (34.89 \pm 1.84$)$ were recorded than in Armagnac genotype (31.32 \pm 1.69$)$. Significant interaction was found between $\mathrm{N}$ and fusarium treatments $(\mathrm{P}=0.023)$. The effect of fusarium infection was observed at optimal N level. Surprisingly, significantly higher SPAD value was recorded in the infected $(33.43 \pm 2.88)$ treatment than in control $(32.33 \pm 1.47)$. However, no differences were found between infected and wounded or between control and wounded treatments. On the other hand, differences between $\mathrm{N}$ levels were significantly increased in infected and injured treatments. In each case, higher values were observed at optimal level of N. Difference was $16.92(40.40 \%)$ in case of infected plants, $11.9(30.13 \%)$ in case of wounded plants and $7.4(20.54 \%)$ in case of control plants. 


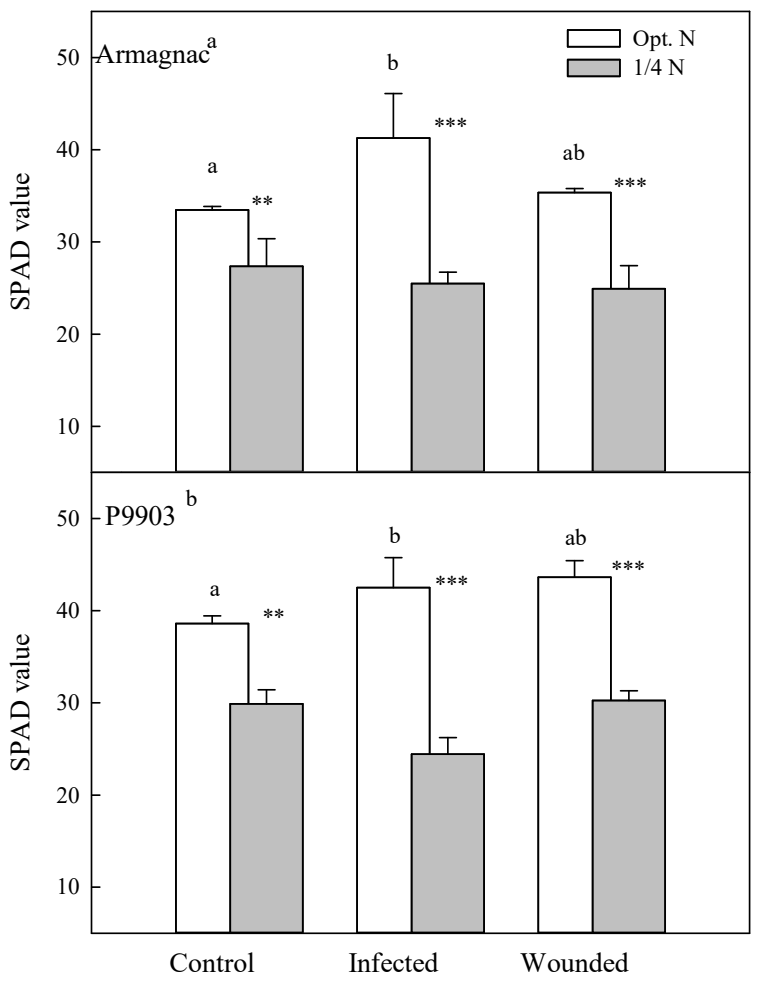

Figure 2. Changes of relative chlorophyll content (SPAD value) in the younger leaves of maize hybrids (Armagnac, P9903) under different N supply (Opt. N, 1/4 N) and due to infection with Fusarium graminearum (Control, Infected, Wounded) $n=3, \pm$ s.e. Significant differences were signed with letters $(a, b, c)(p \leq 0.05)$ and $* * *(p \leq 0.001)$

Indexes calculated from SPAD values are presented in Table 1. Our treatments had no significant effects on these parameters. The values of Nitrogen Remobilisation Rate showed higher values in case of reduced $\mathrm{N}$ level and Armagnac hybrid. Concerning the difference between the SPAD values of oldest and youngest leaf, the highest difference was found in case of optimal $\mathrm{N}$ level in Armagnac genotype (8.73 \pm 5.3$)$. In case of SPAD ratio between the oldest and the youngest leaf, we found similar results. We didn't find any outlier value which can be highlighted in case of RDSI and NDSI.

Table 1. Changes of the Nitrogen Remobilisation Rate (NRR), difference between the SPAD values of oldest and youngest leaf (DSI), SPAD ratio of the oldest and the youngest leaf (RSI), positional difference index between the oldest and the youngest leaf (RDSI), normalized difference SPAD index (NDSI) values by the effect of maize hybrids

(Armagnac, P9903), different N supply (Opt. N, 1/4 N) and infection with Fusarium graminearum (Control, Infected, Wounded) $n=3$, \pm s.e.

\begin{tabular}{|c|c|c|c|c|c|c|c|}
\hline & & & NRR & DSI & RSI & RDSI & NDSI \\
\hline \multirow{6}{*}{ 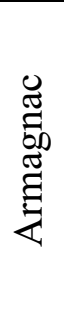 } & \multirow{3}{*}{ opt. N } & Control & $0.8 \pm 0.1$ & $8.73 \pm 5.3$ & $1.26 \pm 0.16$ & $0.26 \pm 0.16$ & $0.11 \pm 0.06$ \\
\hline & & Infected & $0.98 \pm 0.13$ & $0.9 \pm 5.87$ & $1.04 \pm 0.13$ & $0.04 \pm 0.13$ & $0.02 \pm 0.07$ \\
\hline & & Wounded & $0.87 \pm 0.05$ & $5.3 \pm 2.66$ & $1.15 \pm 0.07$ & $0.15 \pm 0.07$ & $0.07 \pm 0.03$ \\
\hline & \multirow{3}{*}{$1 / 4 \mathrm{~N}$} & Control & $1.02 \pm 0.24$ & $-0.23 \pm 6.53$ & $1.02 \pm 0.23$ & $0.02 \pm 0.23$ & $0.0004 \pm 0.12$ \\
\hline & & Infected & $1.08 \pm 0.21$ & $-1.43 \pm 5.23$ & $0.95 \pm 0.21$ & $-0.05 \pm 0.21$ & $-0.03 \pm 0.11$ \\
\hline & & Wounded & $0.89 \pm 0.17$ & $3.1 \pm 5.01$ & $1.15 \pm 0.25$ & $0.15 \pm 0.25$ & $0.06 \pm 0.1$ \\
\hline \multirow{3}{*}{ হे } & \multirow{3}{*}{ opt. N } & Control & $0.93 \pm 0.03$ & $2.97 \pm 1.33$ & $1.08 \pm 0.03$ & $0.08 \pm 0.03$ & $0.04 \pm 0.01$ \\
\hline & & Infected & $0.93 \pm 0.04$ & $3.2 \pm 2.39$ & $1.07 \pm 0.05$ & $0.07 \pm 0.05$ & $0.04 \pm 0.02$ \\
\hline & & Wounded & $1.14 \pm 0.25$ & $-4.73 \pm 8.25$ & $0.90 \pm 0.18$ & $-0.1 \pm 0.18$ & $-0.06 \pm 0.1$ \\
\hline
\end{tabular}




\begin{tabular}{ccccccc}
\hline & & NRR & DSI & RSI & RDSI & NDSI \\
\hline \multirow{4}{*}{$1 / 4 \mathrm{~N}$} & Control & $1.02 \pm 0.05$ & $-0.57 \pm 1.54$ & $0.98 \pm 0.05$ & $-0.02 \pm 0.05$ & $-0.01 \pm 0.03$ \\
& Infected & $0.88 \pm 0.2$ & $3.8 \pm 5.77$ & $1.17 \pm 0.24$ & $0.17 \pm 0.24$ & $0.07 \pm 0.11$ \\
& Wounded & $1.02 \pm 0.17$ & $-0.10 \pm 5$ & $1.00 \pm 0.16$ & - & $0.002 \pm 0.16$ \\
& & & & & $-0.01 \pm 0.08$ \\
\hline
\end{tabular}

\section{DISCUSSION}

Around ten fusarium species toxic for maize, Fusarium graminearum is one of the dominant Fusarium species in Hungary (MESTERHÁZY ET AL. 2011; 2019). The application of non-destructive measurements to detect early non-visible symptoms of fusarium is contested, mainly during the early growth stages, but suitability of SPAD meter to characterization of in vivo $\mathrm{N}$ status was proven by a lot of studies (XIONG ET AL., 2015; YANG ET AL., 2014; SIMKÓ ET AL., 2018). BANDARA ET AL. (2016) found that SPAD value was suitable to detect symptoms of infection in sorghum (Sorghum bicolor L.). In the present study we found interaction between the effects of $\mathrm{N}$ supply and fusarium infection. Nitrogen deprivation significantly influenced SPAD value, but the level of impact depended on the infection treatments. We didn't find any differences between genotypes susceptibility to fusarium infection. Although our results confirmed that the SPAD value is appropriate for detecting $\mathrm{N}$ status, yet indexes from SPAD values were not reliable in detecting $\mathrm{N}$ status, fusarium infection or differences between genotypes in case of maize.

\section{ACKNOWLEDGEMENTS}

The experiment supported by the ÚNKP-20-21 new national excellence program of the ministry for innovation and technology from the source of the national research, development and innovation fund. Project no. TKP2020-IKA-04 has been implemented with the support provided from the National Research, Development and Innovation Fund of Hungary, financed under the 2020-4.1.1-TKP2020 funding scheme.

\section{REFERENCES}

Bandara, Y.M.A.Y., Weerasooriya, D.K., Tesso, T.T., Little C.R. (2016). Stalk rot fungi affect leaf greenness (SPAD) of grain sorghum in a genotype- and growth-stage-specific manner. Plant Disease 10: 2062-2068. DOI: 10.1094/PDIS-02-16-0171-RE

Bata, Á., Rafai, P., Kovács, G. (2001): Investigation and a new evaluation method of the resistance of maize hybrids grown in Hungary to Fusarium moulds. Journal of Phytopathology 149: 107-111. https://doi.org/10.1046/j.1439-0434.2001.00569.x

Bauriegel, E., Giebel, A., Geyer, M., Schmidt, U., Herppich, W.B. (2011): Early detection of Fusarium infection in wheat using hyper-spectral imaging. Computers and $\begin{array}{llll}\text { Electronics in } & \text { Agriculture } & 75(2): & 304-312 .\end{array}$ https://doi.org/10.1016/j.compag.2010.12.006

Broders, K.D., Lipps, P.E., Paul, P.A., Dorrance, A.E. (2007): Evaluation of Fusarium graminearum associated with corn and soybean seed and seedling disease in Ohio. Plant Disease 91(9): 1155-1160. DOI: 10.1094/PDIS-91-9-1155 
Hofer, K., Barmeier, G., Schmidhalter, U., Habler, K., Rychlik, M., Hückelhoven, R., Hess, M. (2016): Effect of nitrogen fertilization on Fusarium head blight in spring barley. Crop Protection 88: 18-27. DOI : 10.1016/j.cropro.2016.05.007

Lin, F.F., Qiu, L.F., Deng, J.S., Shi, Y.Y., Chen, L.S., Wang, K. (2010): Investigation of SPAD meter-based indices for estimating rice nitrogen status. Computers and Electronics in Agriculture 71(1): 60-65. https://doi.org/10.1016/j.compag.2009.09.006

Mesterházy, A., Lemmens, M., Reid, L.M. (2011): Breeding for resistance to ear rots caused by Fusarium spp. in maize-A review. Plant Breed. 131: 1-19. https://doi.org/10.1111/j.1439-0523.2011.01936.x

Mesterházy, A., Tóth, B., Szieberth, D. (2019): A kukorica és őszibúza toxikus gombák okozta megbetegedései. Hazai elöfordulásuk bemutatása toxintérképek segítségével 2012-2017 (Toxic diseases of maize and wheat, occurrence of toxins with toxin maps 2012-2017). Magyar Kukorica Klub. 1: 52.

Muhammed, A.A., Thomas, K., Ridout, C., Andrews, M. (2010): Effect of nitrogen on mildew and Fusarium infection in barley. Aspects of Applied Biology 105: 261-266.

Nagy, L. (2017): Napraforgó hibridek eltérő válaszreakciói baktériumalapú biotrágyakezelések hatására. PhD Thesis, University of Debrecen. Kálmán Kerpely Doctoral School.

Scauflaire, J., Mahieu, O., Louvieaux, J., Foucart, G., Renard, F., Munaut, F. (2011): Biodiversity of Fusarium species in ears and stalks of maize plants in Belgium. European Journal of Plant Pathology 131:59-66. https://doi.org/10.1007/s10658-0119787-1

Shen, Z.Q., Wang, K., Zhu, J.Y. (2002): Preliminary study on diagnosis of the nitrogen status of two rice varieties using the chlorophyll meter. Bulletin of Science and Technology 18(3): 173-176.

Simkó, A., Bodnár, K.B., Veres, Sz. (2018): A SPAD és az NDVI értékek alkalmazhatóságának vizsgálata a relatív klorofilltartalom függvényében kukoricánál. Növénytermelés. 67(2): 45-56.

Singh, N., Rajendran, A., Meena, S., Mittal, G. (2012): Bio-chemical response and hostpathogen relation of stalk rot fungi in early stages of maize (Zea mays L). African Journal of Biotechnology 11(82): 14837-14843. DOI:10.5897/AJB12.1851

Szőke, C., Árendás, T., Bónis, P., Szécsi, Á. (2009): Fusarium stalk rot: a biotic stress factor decisive for maize stalk strength. Cereal Research Communications 37: 337-340.

Szőke, C., Árendás, T., Rácz, F., Pintér, J., Nagy, E., Marton, C.L. (2007): Correlation between maize genotypes and the stalk rot caused by maize Fusarium, Acta Agronomica Hungarica 55(4): 447-452. https://doi.org/10.1556/AAgr.55.2007.4.5

Szőke, C., Bónis, P., Árendás, T., Szécsi, Á., Marton, C.L. (2013): Determination of the fusarium species composition of maize (Zea mays L.) kernel and stalk samples in Hungary. In. Hybrid maize in Hungary is 60 year old. Marton, C.L., Spitko, T. (Eds.), 60 years of Hungarian Hybrid Maize 1953-2013 (pp. 126-130). Hybrid Maize Conference, Martonvasar, Hungary.

Wang, S.H., Cao, W.X., Wang, Q.S., Ding, Y.F., Huang, P.S., Ling, Q.H. (2002): Positional distribution of leaf color and nitrogen nutrition diagnosis in rice plant. Scientia Agricultura Sinica 35(12): 1461-1466.

White, D.G., Hoeft, R.G., Touchton, J.T. (1978): Effect of nitrogen and nitrapyrin on stalk rot, stalk diameter, and yield of corn. Phytopathology 68: 811-814. DOI: 10.1094/Phyto-68-811.

Xiong, D., Chen, J., Yu, T., Gao, W., Ling, X., Li, Y., Peng, S., Huang, J. (2015): SPADbased leaf nitrogen estimation is impacted by environmental factors and crop leaf characteristics. Scientific Reports 5: 13389 doi: 10.1038/srep13389 

DOI: 10.14232/rard.2021.1-2.52-58

Yang, H., Yang, J., Yamin, J., He, J. (2014): SPAD Values and Nitrogen Nutrition Index for the Evaluation of Rice Nitrogen Status. Plant Production Science 17(1): 81-92. https://doi.org/10.1626/pps.17.81 